International Journal of Management Science and

Business Administration

Volume 2, Issue 10, September 2016, Pages 7-16

DOI: $10.18775 /$ ijmsba.1849-5664-5419.2014.210.1001

URL: http://dx.doi.org/10.18775/ijmsba.1849-5664-5419.2014.210.1001

\title{
Contradictions of Formation of the Global Economic Governance System
}

\author{
Nikolay Eletsky \\ World Economy Department, Don State Technical University, Rostov-on-Don, Russia
}

\begin{abstract}
The reasons and the factors of the global economic governance formation became the urgent issues of modern economic theory and practice. Emerging mechanisms of global governance reflect the transitional nature of the present stage of civilization. Under modern conditions, global ownership only begins to form, which inevitably involves the use of the socio-economic shell of previous historical types of economic relations. This particularly reflected in the utilization of the worldwide ownership in private-sector interests and in the application of the mechanisms of global governance to achieve the goals of individual states, corporations, financial-oligarchic clans and other private entities. A contradiction of genesis and evolution of the global ownership and control mechanisms of the world economic system become the essential problem of the international political economy.
\end{abstract}

Keywords: Globalization, Global property, Global governance, Contradictions, Interests of states

\section{Introduction}

The development of modern world economy leads to the profound qualitative transformation of its essential parameters and structural organization. The most important factor of this change is the economic globalization that has affected all the main levels, forms, and elements of the world economic system. Trends of globalization manifest themselves presently in the development of global productive forces, relations of ownership and control in the global market economic mechanism. During and as a result of globalization, the primary economic intrinsic regularities of the source are formed on such a planetary level and then manifest themselves in relation to the economic systems of particular countries, sectors and companies (Ardalan, 2010; Ardalan, 2012; Wolf, 2004).

The evolution of modern productive forces creates the objective need in the formation of the system of global economic governance. This system represents an attribute item, and, along with this, the condition of the further evolution of a new, global-informational technological mode of production. This mode of production, based on the informational resources and forms of wealth, is originally connected with the global scales and mechanisms of economic activity. Information factors of production and forms of wealth genetically embody a quality of universality, which receive an organizational and economical form of embodiment in mechanisms of global governance, attribute for them. However, the new mode of production cannot arise except by the preceding one, and for quite a long historical interval coexists with it, drawing on its resources and gradually subordinating and transforming previous technological and socio-economic elements, parameters, and structure of the production process.

The predecessor of the global informational mode of production is the industrial one, and the peculiar feature of modern productive forces has become the actualization of the need to form global economic governance as a result of unidirectional vectors of the current dynamics of genetically and functionally dissimilar production activities. They are based on the resources as of the traditional type (with progressive limitations), as on the information resources, which socio-economic nature is initially characterized by a quality of universality and unlimited reproducibility. The trends of global informatization and neo-industrialization are dialectically interrelated; it reflects the characteristics of the transition state of the productive forces when the development of industrial technology in modern industries is possible only by means of globalizing informational and computer technologies and globalizing mechanisms of economic management. The globalization of economic governance reflects the contradictory interaction of innovative 
communication elements of the information society's productive forces and the need (centralized in planetary scale) to regulate the use of dwindling traditional resources.

\section{Problem Statement: Content and Structure of Contradictions}

We can assume, that the main contradictions of the emerging global economic governance are (in a reduced and schematized form) the following key interrelated contradictions:

- between the realization, in the process of global economic governance, of the interests of all humankind, on the one hand, and interests of top-down social structures (states, corporations, groups, etc.), on the other, and above all between globalization and Americanization;

- between the principle of universality of global governance and the principle of nation-state sovereignty (between globalization and "Westphalian system");

- between the two main models of global governance - "Global economic organizations as the world economic government" and "Government of the dominant power as the world government";

- between the objectives of financial and real sectors of the world economy;

- between globalization and regionalization (the contradictions of "glocalization").

The first of these contradictions has the substantial and ontological nature and is due to the impossibility of "instantaneous" appearance of the social system in formed and expanded mode (Arrighi\& Silver, 1999). New social phenomena in the process of their genesis and evolution arise and operate within and through previously existed, antecedent social shells and mechanisms. The universality of global governance is also apparently contrary to the principle of nation-state sovereignty (historically formed under conditions of the "Westphalian system"). Global governance implies the unification of economic interactions and procedures, while the existence of national borders contributes to the reproduction of the features of these interactions and reflects the continuing objective special interests of individual States.

This complex of contradictions most clearly manifests itself in the framework of the European Union. Being a regional integration group, the EU simultaneously acts as a global actor in the field of economic interactions and as the vivid expression of the dialectic of "glocalization". "There is no other example in history of nation-states willing to pool so much sovereignty in some domains while at the same time retaining so much autonomy in others" (Navratil, 2015, p.199). The emergence, development, and overcoming of conflicts between national states and supranational institutions of economic governance are taking place now in the context of the contradictions between the financial and real sectors of the economy and regarding solving the problems of re-industrialization. Institutions and mechanisms of economic governance that have emerge $\mathrm{d}$ within the $\mathrm{EU}$ are at the same time a preliminary model, a prototype of the future system of global economic governance.

\section{Methodology: Genesis of the Global Property Relations}

The formation of the global property and global governance is a long and controversial process, at each stage of which actors of the global interactions seek to protect their interests. At this, there appears the relationship of the genesis of the global property and the formation of institutions and instruments of global economic governance. For nation States, this is currently of particular importance with regard to possible ambiguous aspects of their integration into global processes (Kovarova, 2015).

The formation of a global property occurs through various mechanisms, procedures, and methods. The most obvious of these mechanisms involve direct recognition of certain objects as a property of all humanity and the legal sanctioning of such recognition in the form of a contract between the leading actors of global interactions, with simultaneous or subsequent accession to this agreement the majority of other subjects of international relations. The most famous examples of this mechanism are the system of agreements on the use of common resources of the World Ocean, the Antarctic Treaty, and the Outer Space Treaties. The subjects of such treaties or agreements usually are the States, while in some cases an additional factor of international legitimacy is the conclusion of treaties under the auspices or with the participation of recognized global organizations, primarily the UN. 
Thus, in the Preamble of the UN Convention on the Law of the Sea it's directly defined, that «the area of the seabed and ocean floor and the subsoil thereof, beyond the limits of national jurisdiction, as well as its resources, are the common heritage of mankind, the exploration, and exploitation of which shall be carried out for the benefit of mankind as a whole, irrespective of the geographical location of States». This provision is specified further in part VII ("High Seas") of the Convention, which fixes, that "the high seas are open to all States, both coastal and landlocked" (article 87, "Freedom of the high seas") and "no State may validly purport to subject any part of the high seas to its sovereignty" (article 89 "Invalidity of claims of sovereignty over the high seas") (UN, 1982). It is obvious that the wording means a direct legal fixation of the world ownership of objects and resources of a significant portion of the World Ocean and reflects the legal consolidation and the streamlining of the previously established economic system of the actual realization of the world ownership of these objects.

The Antarctic Treaty and other related international legal instruments, which constitute the Antarctic Treaty System (ATS), reflect the characteristics of the initial stage of formation of the legal status of the world property through the signing of intergovernmental agreements. On the one hand, the requirement to demilitarizing the nature of the activity and the proclamation of the freedom of research, in fact, implies that Antarctica is considered as the world domain. This, in particular, directly reflects the wording of the Preamble of the Treaty: "it is in the best interests of all of the mankind that Antarctica shall always continue forever to be used exclusively for peaceful purposes and shall never become the scene or object of international discord"; "the establishment of a firm foundation for the continuation and development of such cooperation on the basis of freedom of scientific investigation in Antarctica... accords with the interests of science and the progress of all mankind" (The Antarctic Treaty, 1959). On the other hand, the Treaty does not deny the legitimacy of the territorial claims of individual States in Antarctica ("Nothing contained in the present Treaty shall be interpreted as... a renunciation by any Contracting Party of previously asserted rights of or claims to territorial sovereignty in Antarctica" (Ibid. A. IV, 1, a.). As a result to date it turned up the contradictory and uncertain situation: a number of States declared their territorial claims to large areas of the Antarctic, and in some cases on the same territory claimed by the several States (neither the U.S. nor Russia do not make such claims and do not recognize claims of other States). Note that the ice of Antarctica contains $80 \%$ of world volume of freshwater, and taking into consideration the progressive scarcity of this resource, it will inevitably aggravate the problem of the proprietary status of its global stockpile.

With the expansion of outer space explorations there actualize the problems of the ownership of space objects. The peculiarity of the wording of the Outer Space Treaty is, on the one hand, clearly defining outer space and space objects as the domain of all mankind, and, on the other, reflecting the conditional nature of the application of property concepts to extraterrestrial objects. ("The exploration and use of outer space, including the moon and other celestial bodies, shall be carried out for the benefit and in the interests of all countries, irrespective of their degree of economic or scientific development, and shall be the province of all mankind... Outer space, including the moon and other celestial bodies, is not subject to national appropriation by claim of sovereignty, by means of use or occupation, or by any other means" (Treaty on Principles Governing the Activities of States in the Exploration and Use of Outer Space, including the Moon and Other Celestial Bodies , 1967). If the considered objects are not the objects of space origin ("celestial bodies") but are the objects launched from Earth into outer space, these objects apply traditional norms of proprietary relations and entitlements, fixed by the "Convention on Registration of Objects Launched into Outer Space" (UN, 1974), with the amendment that defined in this Convention liability for damage caused by launched space objects, indirectly recognizes the space, including near-earth space, as object international proprietary relations.

Expansion of existing and emergence of new areas of activity related to the exploration of space and, especially, the use of funds of private individuals for this activity (launch of private spacecraft, the development of private space tourism, etc.), revealed the incompleteness of the modern system of space law, including, in the aspect of proprietary relations. Thus, the status of outer space and celestial bodies as a domain of all humanity tied in existing international space treaties with the prohibition of distribution of sovereignty of individual States on these objects without reference to the eligibility of individual persons, and it became the basis for active speculation on the part of individual entrepreneurial entities. Today, the "Lunar Embassy", the sale of plots on the moon, Mars and other cosmic bodies can still be perceived as a curiosity and charlatanism, but in the foreseeable future specification, proprietary powers relating to activities in outer space can become an actual problem. 
In contrast to the relations regulated by the international treaties, expressly define certain objects of global significance as a possession of all humankind, technically more complex and indirect mechanisms of formation of world property rights arise through agreements that have functional or branch specificity. So, as a mechanism for the institutionalization of the global property rights to the global atmospheric resources can be, for example, considered the international agreements under the Montreal and Kyoto protocols ("Montreal Protocol on Substances that Deplete the Ozone Layer", 1987; "Kyoto Protocol to the United Nations Framework Convention on Climate Change", 1997) and decisions of the United Nations Climate Change Conference (Paris, 2015). The definition of limit of global harmful emissions to the atmosphere through the establishment of quotas of individual States can be seen as a consequence of actual recognition of the atmospheric air as the property of all mankind and the development of mechanisms for the use of this global resource by the entities of downstream social levels on the basis of the principles established and recognized on a global scale. Failure to recognize these principles by some States reflects the gradual and contradictory process of formation of global property under preservation of not only differences, but also diverse variants of opposites of global interests to the interests of national states, and especially to the interests of the private sector (Global Economic Governance Program, 2016).

The quota arrangement of harmful emissions into the atmosphere is concurrently an indirect form of limiting production in the relevant industries. Such limitation can be carried out directly - that's what happens in global oil production in accordance with OPEC decisions. The activities of this organization as by setting quotas of oil production and, through this, - by regulation of oil prices and the income level of the participating countries - can also be seen in the context of the process of formation of global property for the oil resources. The mentioned mechanism, in essence, determines the global income in this industry, and appropriation of income from the operation of the factor of production serves as the main form of economic realization of ownership on this factor. Along the way, OPEC's activity shows the dynamics of the dialectics of formation of global property and mechanisms of its interaction, at the stage of formation, with other, preceding and socio-descending proprietary relationships. The elements of actual usage of the resource as a worldwide are difficulty combined with the assignment of revenues at public and private levels.

The manifestation of the transient nature of economic relations in the process of the formation of global property, it can also be observed in the activities of the largest TNCs, transforming into a global corporation (GC), as well as in activities of their alliances. These corporations carry out the assignment of certain types of resources and the production of certain products on a global scale; they also set world market prices and profitability criteria in their respective sectors and sub-sectors of the global economy, from a technological and consumer standards, conduct globally significant scientific research and determine strategic directions of development. However, these corporations assign income by traditional principles and mechanisms of private property; the processes of global and privatecorporate appropriation of revenue be identified.

Emerging, as a result of the activity of GCs, "world profit" reflects the economic parameters of operation of the respective sectors and subsectors at the global level. Although its volumes depend on the ongoing by monopolies "optimizing" of the prices, incomes, and tax payments through transfer pricing and movement of income to countries with a liberal tax regime ("tax havens") using a whole system of measures (non-residents dividends, interest of foreign lenders, royalties and lease payments, etc.), the essence of problem is not in it - it's in the new economic nature of world profit. It embodies the global nature of property relations formed on the basis of the GC activities and not reducible to state-discrete economic relationships. The task of determining the exact amount of income ledger, subject to tax in certain country, and "fair" (from the point of view of individual States), economically and legally correct fixation of the GCs tax base is unsolvable in principle. This is due to the fact that the world profit by its real economic nature is the phenomenon of global, rather than state-discrete character, and it really has a global integrative-systemic nature, not reducible to the formal sum of the profit received by the divisions of these corporations in different countries.

Therefore, in actual use in modern international practice the five basic methods of determining the profits of TNCs with regard to transfer pricing, there are suggestions about switching to the method of "global formula apportionment" (GFA). This method involves calculating the global profit of TNCs and taxation with reference to the activities of all divisions on a global scale with division of the taxable base for certain state jurisdictions through integrative coefficients, reflecting the proportion of the corresponding state (specifically - affiliates of TNCs operating in this state) in the main production and financial indicators of the Corporation - the amount of assets, sales, employment, 
etc.(Lindsay, 2000).The concept and formulation of the method of global proportional distribution (GFA) embodies the idea of a political-economic nature of TNCs as subjects of global ownership, operating in forms of discrete-state separation of global market, - forms, relict for them.

Transitional nature, reflecting the process of establishment of the global proprietary relations, is manifested not only concerning the productive resources but also towards other objects, such as objects of cultural heritage, defined as world possession. Located on the territory of particular States, such facilities are, however, subject to surveillance, monitoring and partial funding from international organizations. The transitional nature of the relationship is manifested in this case in a different aspect - objects of the world cultural heritage can also be seen as tourist resources used on the basis of traditional economic principles and as the phenomena of non-economic, civilizational order with the increasing dominance of spiritual values criteria. It is obvious that this domination will become predominant in future.

But the greatest prospects in the foreseeable future are inherent to the directions of development of world property due to the transition to a new, global-information mode of production. In the economic system of this mode of production, the role of the main resources and the main forms of wealth goes to the phenomena of information nature; it's changing as a subject structure of property relations. Herewith at the early stages of a new mode of production, it remains the influence of traditional forms of property which existed in preceding ages. Therefore, the mechanisms of ensuring and protecting the profits of information resources owners and, in particular, intellectual property rights become an important social problem. However, in the process of the developing and strengthening of the role of information forms of wealth, qualitatively new social nature of these structures becomes increasingly evident. First of all, this relates to the nature of information as a universal resource and wealth, to the "all-pervasive" character of information, to the universality of its distribution, application and use. The monopolization of private appropriation of the universal resource is not only inadequate to the new principles of social interactions, but also technically impossible one and this is the most profound objective basis of those social contradictions that surfaced in the modern world, for example, in connection with attempts of practical implementation of the "anti-piracy" laws). The nowadays reality is the possibility of free use of enormous amounts of information contained in global information networks, and use free or for a nominal fee that reflects a new social phenomenon - the emergence of the system of the world ownership on information with the identification of all mankind and all the descending levels of social subjectivity, up to the individual person, as the subject of property.

\section{Analysis of the Results: Relationship of the Contradictions of the Global Property and Global Governance}

\subsection{Features of Models of Global Economic Governance}

The analysis of globalization of productive forces and property relations allows answering the question "why" there is an objective necessity of global economic governance. In turn, the answer to this question inevitably leads to logically following from it new questions: "who", "how" and "why». Who controls the global economic process, who is the subject of managerial decision-making in the world economy? How, through what mechanisms is this governance realizing? And why, i.e. in whose interests is it carried out? In the last decades there arose, transformed, and interacted numerous "sprouts", the elements and institutions of global governance; there identified diverse aspects of their incompleteness, imperfection, and lack of effectiveness - but, at the same time, it became increasingly obvious inevitability of their future development, overcoming the typical for initial stage restrictions, the objective necessity of improving and strengthening the role of global governance structures in the regulation of planetary processes.

Because the property is a social-economic form of appropriation and, in the first place - assigning of factors of production, so the contradictions of the genesis of global economic governance due to the contradictions of global property, in accordance with the general pattern of implementing the management as a function of property. At the same time, on the other hand, the genesis of the global economic governance depends on mechanisms of global political governance, which formation occurred much faster and more intense due the social nature of politics as concentrated economics and the specifics of international military-political contradictions in the nuclear age. In this regard, it is quite natural that the leading institutions of global economic governance were created under the auspices of the UN - organization, initially oriented for regulation of military-political problems and disagreements. However, the apparent interconnectedness of political and economic regulation has led to the fact that at the stage of preliminary 
negotiations about the establishment of the UN key decisions concerning the global structure of postwar financial and monetary system (Bretton-Woods conference) were adopted. Then, there were rather quickly agreed the modified principles of international trade (GATT), and the UN Integrated previously encountered globally significant economic organizations (ILO).

As a result, in the framework of ECOSOC it formed although organizationally amorphous, but functionally viable prototype, "a draft version" of the global economic government. The actions of that government had fragmented and situational character, were dispersed in separate, few agreed with each other industries and functional areas and projects. Nevertheless, the appearance and aging of the elements of global economic governance, particularly in the areas of international finance and international trade, had a place. The contours of the typical algorithms of the Genesis of these elements were delineated in accordance with the law "the function creates the organ». As a rule, on the basis of international agreements there arose the institutions of implementation of these agreements and monitoring of their realizing, which, in a case of growth of objective global significance, transformed into the bodies of global governance. Similar mechanisms were observed in the activities of the GATT/WTO (Fojtikova, 2015), IMF, WB, OECD, ILO, IAEA, OPEC and other organizations(as well as global governance in the sphere of political and legal relations - in the activity of UNSC, UNESCO, WHO, international courts, etc.). We can say that as a result of these processes such organizations as the IMF, WB, FSB have become in a number of aspects of their activities to acquire the functions of the divisions of the global Ministry of Finance, just as WTO, WCO, UNCTAD, UNCITRAL - functions of the divisions of the global Ministry of trade.

The tendency of a transformation of the economic structures of the UN to the real world economic government was inhibited by the collapse of the bipolar world order. The UN ceased to be an instrument of balancing the interests of the two superpowers, and simultaneously there has been an overall decline of the global role of this organization. Another mechanism of global governance has come to the fore, and this was associated with the performance of global governance functions by the government of the strongest power. In these conditions the content of the work of many UN agencies has changed-retaining the shell of international organizations, they are, in fact, turned into instruments of realization of the United States interests. The government of this power had exercised functions of global governance, seeking to subdue the course of global processes to its purposes. The most obvious examples of this mechanism are embodied in the activities of such financial institutions as the IMF and the World Bank. Their status in the UN structure became more and more formal, while real activities, in cooperation with the functions of the Fed as the regulator of the global monetary and financial relations, turned into the elements of the dollar seignior-age mechanism, which provides the US the possibility of consumption about $40 \%$ of the world's gross product, with percentage in its production about $20 \%$. From time to time the United States show its dominance over international organizations (and not only economic), changing arbitrarily their leadership, "guilty" of real or imaginary attempts of independent policy-making as it was, for example, against the heads of the IMF, FIFA, and FIDE.

At the same time, the increasing role of global financial institutions under the auspices of the US reflected another key feature of recent decades - the growing importance of the financial sector of the global economy and its dominance over the real one. Individual industries and sectors of the world economy are subject to direct control by the globalizing TNCs and international organizations, while the world economy as whole is generally regulated indirectly, through the dollar mechanism of international payments and instruments of speculative financial capital. The results of such regulation, from the point of view of the problem of world economy sustainable development, are contradictory: on the one hand, the insurance and reinsurance of risks in the real sector of the economy and hedging financial transactions, "spray" the risks and potential and actual loss of different etiology on the entire global economic network, minimizing them at the micro level; on another hand - effect of the "inverted pyramid", due to the multiple excess of total derivatives over volume of the real trade of non-financial goods and services, creates instability and uncertainty of the status and development of the whole system of the world economy. For nearly a quarter of a century a number of eminent experts (including Nobel laureates in Economics), focusing on the first of the given phenomena, expressed the opinion that in modern conditions global economic crises are impossible.

However, the events of 2008-2009 (Dvoroková, 2014) and the subsequent confusions of the global economy have discovered the falsity of this opinion; it was found that minimization of micro risks and their "dissolution" in the global economic-financial network are not identical to the strength of the network itself: it is prone to systemic global risks that are due to the sharp disproportionality of the speculative financial and real sectors of the world economy and the 
contradictoriness of functions of dollar as the world reserve currency, on the one hand, and national currency on another hand. The global financial and economic crisis has become a watershed event in the development of the system of global economic governance in two important aspects: firstly, it demonstrated the historical ultimacy of the unipolar management model; secondly, it revealed the inefficiency of the management of global economy on the basis of submission of real sector to the speculative finance one. Both of these aspects are reflected in the "reformatting" of the system of international economic relations and management through the transition to "multipolar" global governance and strengthen control over the activities of global financial institutions. The concrete manifestation of this tendency is found in the establishment of a new global status and a radical expansion of the functions of the "G-20" and in the dominant orientation of the managerial impacts of this group on the problems of global financial relations. In addition, it became noticeably manifest sharply growing the global economic role of China, Newly Industrialized Countries, and new economic organizations and associations, such as the BRICS, SCO, AIIB, TPP (Desai,2013). The urgent need for fundamental change of the nature of interrelations between real and financial sectors of the world economy was clearly detected also in connection with the task of re-industrialization of developed countries. The USA's attempts are obviously aimed to complicate the processes of re-industrialization in the EU and Russia; these attempts are designed for diversion of their resources to military-political conflicts and the problem of migrants. Through this US crave to retain the role of primary center of global economic governance; the same goal is pursued by the establishment of the proposed TTIP and especially ISDS mechanism in its framework (Vaníčková, Zeman \& Bílek, 2014).

The system of contradictions of global economic governance also includes the contradictions between TNCs and the principle of state sovereignty of individual countries. Especially sharply these contradictions are manifested in relation to small and medium-sized countries, unable to effectively defend its sovereignty in opposition to the GCs, primarily for economic reasons. It's known that the cost of products manufactured by ten largest GCs, exceeds the combined GDP of one hundred countries with small volumes of the economy. To some extent these contradictions are also evident in the attitude of large countries, but in interactions with them GCs strive for the reconciliation of interests and the use of the military-political capacity of major powers as a tool to achieve their economic goals and to guarantee favorable conditions for the functioning (Kurecic \& Kampmark, 2016).As a result, to date, formed a kind of symbiosis of the GCs and the military-political apparatus of the major powers to form a mutually beneficial mechanism of the global economic and political governance.

\subsection{Actual Problems of Development of Financial and Informational Instruments of Global Economic Governance}

To date, the mechanism of global governance generally and the mechanism of global economic governance particularly revealed the special role of informational and financial tools (Desai \& Vreeland, 2011). The key importance of these instruments is due to the intrinsic internal characteristics of the present stage of economic civilization, whose technological side of the production method corresponds to the parameters of the information society, and socioeconomic - to the global financial stage of the capitalist socio-economic formation. Informational unity of the global social system, the material basis and prerequisite of which are elements of modern productive forces, embodied in information and communication technology (ICT), determines the role of information tools in the framework of global governance. A continuous flow of economic information reflects the results of the current state and prospects of development of world economy, as well as national and regional economic systems. Informatively significant trends of their evolution represented in widely available forecasts on a short, medium and long term. Similar information is also continuously reproduced pertaining to business and financial units and complexes - firms, banks, MNCs, financialindustrial associations etc. Bourse, banking, insurance, rating and other information platforms conduct as ongoing monitoring, as extrapolation modeling of economic processes at the macro, meso and micro levels. Price information signals are of key importance for the market, and the world market system operates in a mode of continuous analysis of pricing information, including the financial markets quotes.

However, the movement of economic information, as well as all socially relevant information generally, by no means is the spontaneous process. Production, selection, and dosage, grouping and summarizing, the hierarchy and outline, flow and interpretation of information are carried out consciously; they are performed by the subjects of global governance and act as the implementation of their economic power mechanism. Not by chance this issue was in the spotlight in connection with the discussions of the causes of the global financial-economic crisis of 2008-2009, as well as in the context of searching for ways out of it and prevents similar upheavals in the future. The global crisis as a "crisis of confidence", the essential attributes of modern global markets as markets of expectations and markets of risks are inseparable from the production of economic information and management of information. That is why at the meetings 
of the "G-20" the need of strengthening of control over the informational activities of rating agencies had highlighted as the urgent measure for the prevention of provoking crises. The global credit ratings' market has been formed as an oligopoly structure. The "big three" of the New-York agencies is its backbone. Standard \&Poor's captured $40 \%$ of the global market, Moody's - also 40\%, Fitch - 10\%.Mentioned "big three" bears a significant share of responsibility for the "unwinding" of the global crisis and for provoking some other crises and some negative phenomena in the economy of many countries (including the United States)."Twenty" demanded to increase the information transparency of rating agencies, to disclose the methodology of their estimates, to resolve conflicts of interests, to tighten government regulation (registration, oversight), to reconsider model "The Issuer pays for the rating", the result of which often is bias estimates and projections, leading to economic losses of macro- and microeconomic subjects.

It is no secret the political engagement as mentioned, and other manufacturers of different kinds of ratings, including in scientific and educational spheres. Arbitrary and artificial criteria, which do not reflect the real situation in various spheres of economic and social life, become an instrument for inter-country and inter-firm competition and means of realizing the interests of the most powerful actors in global interactions, aggravating thereby the already acute contradictions of globalization. The reflection of these contradictions was expressed in the tendency of a creation of national rating systems in various fields to promote national and state information and economic security and sovereignty (Honová \& Hon, 2014).

When the market-capitalist system reaches the stage of global finance capital, the global information management in the financial sector becomes the leading value in the mechanism of the information support of control actions on the economic processes. The subjects of the control over the movement of global financial flows have become key actors in the management of the world economy as a whole. Global finance capital is personified in closely intertwined groups of world financial oligarchy, the representatives of which constitute the real global economic government. Furthermore, the leading actors of international economic interactions have reached agreement on strengthening the functions of the hardware structures of the G-20 in the regulation of global financial relations, in this connection the Forum for financial stability, established in 1999, was at the London summit (2009) transformed into the Financial Stability Board (FSB) with significantly enhanced functionality. The Board has subsequently included in its composition the Ministries of Finance and Treasuries of the countries of "twenty", their Central banks and regulators, and leading international economic and financial organizations (OECD, WB, IMF, BIS, ECB, European Commission) and international institutions settings standards (Basel Committee on Banking Supervision, the Committee on the Global Financial System, Committee on Payment and Settlement Systems, International Association of Insurance Supervisors, International Accounting Standards Committee, International Organization of Securities Commissions).It's actively discussing the idea of concluding an international Treaty for a global legal institutionalization of the functions of the FSB to give it a supranational authority, the binding nature of its decisions to national jurisdictions and the corresponding transfer of part of the financial sovereignty of States. Such institutionalization, in case of its international legal registration, would be a decisive step towards the legal recognition of the existence of a world economic government, or, at least, its financial unit, which, in cooperation with WTO and other global international organizations would be transformed into a real mechanism of control the world economy. The persistence of the current system, without giving FSB supranational functions, is fraught, according to experts, with a danger of fragmentation of the global financial system. Very likely becomes the reproduction of the risk of a new global crisis, the emergence and the "popping" of new financial bubbles and bankruptcy of the globally significant financial institutions (defined, from the point of view of the world economy's stability as "too-big-to-fall").

The contradictions of the "financial trilemma" (the simultaneous achievement of financial stability, development of financial integration and national financial policies), the difficulties of establishing a Single Supervisory Mechanism (SSM), soreness and the asymmetry of gains and losses from the restriction of monetary sovereignty depending on the relative strength and weakness of the subjects of integration interaction - these and other contradictory factors act as objective constraints in the formation of mechanisms of global financial governance. Opposing impulses manifest themselves as trends of moving to national and regional currencies in bilateral and multilateral calculations. We must also take into account the role of political contradictions, which are the most important reason for the desire to create national payment systems in order to ensure national economic security.

Considered processes are connected with the obvious fact that the performance of global governance functions requires adequate material and financial resources. In the model of "the government of the strongest power as world 
government" part of the global resources distributed through the financial mechanism for the United States, is used by the government of this State for the regulation of global processes. Global regulation undertaking by TNCs is realized by financial means (more specifically - monopoly-high profit) of these corporations. Activities of international organizations, including management, are based on resources accumulated from the contributions of countries and organizations participating. Single (to authorized capital) and/or periodical contributions, in fact, become elements of an emerging system of global taxation. The diversity, fragmentation, and uncertainty of the principles and mechanisms of these fees reflect the conditions of the initial stage of the emergence of this system, and the constant replay of certain elements and the emergence of new ones demonstrate the sustainability trends of its development and strengthening.

Noted mediated mechanisms of the actually encountered global taxation combined with a constant discussion of the proposals for the introduction of its open and direct forms - and, especially, in an embodiment of the percentage allocations of GDP on accounts of the specialized tax and financial departments of the UN. However, specific proposals on this issue triggered many objections from the participants of global economic interactions. Another widely discussed proposal is the concept of so-called extended "Tobin tax", under which, the objects of taxation are speculative financial transactions. Even with a minimal rate on the order of 0.1-0.25 percent, making the tax almost imperceptible for participants of financial transaction, it would be currently worth more than a trillion dollars annually. Prospects as noted above and other hypothetical models of direct global tax depend on the subsequent evolution of subjectivity of the planetary governance and resolution of related conflicts. Potential consent of globally important economic actors for the introduction of a system of permanent direct global taxes depends on their confidence about the fairness and effectiveness of the use of derived tax funds by the world government.

\section{Conclusion}

The formation of the global property and governance is inherently an objective process, but its specific implementation may take various forms with different potential of contradictions. These contradictions reflect the transitional nature of the present stage of civilization. Abstract definitions of global economic governance as a phenomenon designed to achieve the interests of all humankind face with the practical impact of previous historical forms of private appropriation. The real transformation of planetary resources to being the domain of all humankind - is a matter for the future.

Also, note that the formation of the global property and governance is a long historical process, during which there are possible changes, sometimes very significant, of position and role of individual actors of the world economy in its structure and hierarchy. In the last decades, it was convincingly demonstrated, for example, by the NICs and, especially, by China. At each new stage of globalization, participants of international economic relations meet new challenges to improve the efficiency of integration into the world economic system, to strengthen international competitiveness and prospects for further development.

Various aspects of the contradictions of global economic governance constitute the object of study for such scientific disciplines as "world economics", "international economic relations", "geo-economics», «geopolitical economy", "economic globalists" and several others(Global Political Economy, 2008; Desai, 2013; Issues and Actors in the Global Political Economy, 2016; Review of International Political Economy, 2016).For each of these Sciences, the politicaleconomic approach, identifying the content, role, and contradictions of property relations, is the methodologicaltheoretical basis. At the same time, being allocated, generalized and systematized as a distinct research direction, this approach forms the subject of special branch of modern scientific knowledge - that's the global political economy.

\section{References}

- Ardalan, K. (2010). Globalization and Global Governance: Four Paradigmatic Views. American Review of Political Economy, vol. 8(1) 6-43.

- Ardalan, K. (2012). Globalization and World Order. Journal of Globalization Studies, vol. 3, n. 1, 39-54.

- Arrighi, G., Silver, B.J. (1999). Chaos and Governance in the Modern World System. University of Minnesota Press, Minneapolis. -336 p.

- Desai, R. (2013). Geopolitical Economy: After US Hegemony, Globalization and Empire. The Future of World Capitalism. London: Pluto Press, and Halifax: Fern-wood Publishing. - 313 p. 
- Desai, R.M., Vreeland, J.R. (2011). Global Governance in a Multipolar World. International Studies Review, (13) 109-121, CrossRef

- Dvoroková, K. (2014). Impact of Economic Crisis on the International Monetary System. In International Conference on European Integration. Ostrava: VŠB-TU Ostrava, Faculty of Economics, 110-118.

- Fojtikova, L. (2015). The Changes of International Trade Policy: Liberalization vs. Protectionism. In The World Economy Transformation: Problems and Trends. Rostov-on-Don: Publishing Center of Don State Technical University, 92-117.

- Global Economic Governance Program (2016). Research [online]. [cit.2016-08-28]. Available: http://www.globaleconomicgovernance.org/research

- Honová, I. and Hon, M. (2014). Competitiveness Indices Methodology and Its Impact on Ranking of Selected EU Countries. In International Conference on European Integration. Ostrava: VŠB-TU Ostrava, Faculty of Economics, 253-261.

- Ibid. A. IV, 1, a.

- Issues and Actors in the Global Political Economy (2016) [online]. [cit.2016-08-28]. Available: http://www.academia.edu/5123463/Issues_and_Actors_in_the_Global_Political_Economy

- Kovarova, E. (2015). Impact of the Globalization on Nation-States and their Economies. In The World Economy Transformation: Problems and Trends. Rostov-on-Don: Publishing Center of Don State Technical University, 39 58.

- Kurecic, P., Kampmark, B.A. (2016). Multifarious, Multifaceted Approach to the Multipolar World: a Necessity. International Journal of Management Science and Business Administration, vol.2, n. 8, 42-51, CrossRef

- Lindsay, C. (2000). The formulary approach to the taxation of transnational corporations: a realistic alternative? [Online]. [cit.2016-08-28]. Available:

- Navratil, B. (2015). Economic Governance in the European Union. In The World

- Review of International Political Economy (2016) [online]. [cit.2016-08-28]. Available: https://www.researchgate.net/journal/1466-4526_Review_of_International_Political_Economy

- The Antarctic Treaty (1959). [Online]. [cit.2016-08-28]. Available: http://www.nsf.gov/geo/plr/antarct/anttrty.jsp

- Treaty on Principles Governing the Activities of States in the Exploration and Use of Outer Space, including the Moon and Other Celestial Bodies (1967). A. I, II. [online]. [cit.2016-08-28]. Available: http://disarmament.un.org/treaties/t/outer_space/text

- UN (1974). Convention on Registration of Objects Launched into Outer Space [online]. [cit.2016-08-28].Available: http://www.un.org/ga/search/view_doc.asp?symbol=A/RES/3235 (XXIX)

- UN (1982). United Nations Convention on the Law of the Sea [online]. [cit.2016-08-28]. Available: http://www.un.org/depts/los/convention_agreements/texts/unclos/unclos_e

- Vaníčková, R., Zeman, R. and Bílek, S. (2014). Transatlantic Partnership and Its Political-legal, Trade and Socioeconomic Impacts. In International Conference on European Integration. Ostrava: VŠB-TU Ostrava, Faculty of Economics, 740-745.

- Wolf, M. (2004). Globalization and Global Economic Governance. Oxford Review of Economic Policy, vol. 20, n. $1,72-84, \underline{\text { CrossRef }}$ 